DOI: 10.1515/auseur-2017-0003

\title{
Concepts of Citizenship in Eastern and Western Europe
}

\author{
Edith OLTAY \\ PhD Student, National University of Civil Service Budapest \\ E-mail: Edith_Oltay@web.de
}

\begin{abstract}
The classical meaning of citizenship evokes a nation-state with a well-defined territory for its nationals, where national identity and sovereignty play a key role. Global developments are challenging the traditional nation-state and open a new stage in the history of citizenship. Transnational citizenship involving dual and multiple citizenships has become more and more accepted in Europe. Numerous scholars envisaged a post-national development where the nation-state no longer plays a key role. While scholarly research tended to focus on developments in Western Europe, a dynamic development also took place in Eastern Europe following the collapse of communism. Dual citizenship was introduced in most Eastern European countries, but its purpose was to strengthen the nation by giving the ethnic kin abroad citizenship and non-resident voting rights. In Western Europe, the right of migrants to citizenship has been expanded throughout the years in the hope that this would result in their better integration into society. Eastern Europe and Western Europe operate with different concepts of citizenship because of their diverging historical traditions and current concerns. The concept of nation and who belong to the national community play a key role in the type of citizenship that they advocate.
\end{abstract}

Keywords: citizenship, double citizenship, minorities, national minorities, migration, integration, multiculturalism

\section{Definition of Citizenship}

Citizenship can be defined as a membership in a political and geographic community, where there is the closest legal relationship between a state and a person, in which both have the widest reaching rights and obligations. Historically, the nation-state had a distinct territory and provided the administrative framework to protect its citizens and to ensure their rights on its territory. The state protected the citizens who in turn respected the laws and paid taxes (Szabó 2013). One can divide citizenship into four dimensions: legal status, rights, political and civil participation in society, and a sense of belonging (Bloemraad 2008: 154). 
On the legal level, one can become a citizen based on the principles of ethnic origin (jus sanguinis) or/and birth on the territory of the state (jus soli). Naturalization was introduced for residents who were not born in the country. Citizenship has political and civil dimensions, too. Citizens can vote and elect their representatives and minors and foreign residents are given opportunities for participation in other fields of political and civil life. On the psychological level, citizenship furthers the individual's sense of belonging to and identification with the state. It is an important element of social cohesion in today's societies (Weil 2011). The citizen becomes the member of an 'imagined community' which was constructed out of cultural traditions that make up the nation-state (Anderson 1983).

Nation is a central element throughout Europe. The definition of nation, of who belongs to the national community is the key to understanding the citizenship policies that nation-states pursue. Historically, European nation-states engaged in nation-building and established the social cohesion needed to engender loyalty toward the state. 'Belonging' is central to nation-building throughout Europe. All Europeans belong to a nation, some to two or more nations, but there are hardly any individuals who are nationless. Over $99 \%$ of all human beings are citizens of a nation-state and possess passports or national IDs that confers upon them a legal status (Weil 2011, Kántor 2014). The situation of statelessness is conceived of as temporary, and individuals as a rule strive to be citizens of a state that can protect them. Possessing a citizenship, being the member of a political community which protects the individual means the possession of basic rights or, as Arendt put it, the 'right to have rights' (Arendt 1973: 230-231). 'At a practical level, without institutions such as courts and policing apparatuses, it is unclear how rights can be guaranteed absent a state-like structure' (Bloemraad 2008: 164). For Seyla Benhabib, the 'right to have rights' encompasses the universal human rights of refugees to gain entrance into nation-states through 'porous borders' even if they are not citizens. The question is how these rights can be implemented since nation-states regard it as their sovereign privilege to decide whom they admit as migrants and to whom they grant asylum. They also differentiate between citizens and residents who do not have full citizenship rights. Benhabib advocates the establishment of different models of nation-state under which a nation-state accepts restrictions on its sovereignty (Benhabib 2004).

\section{New Citizenships}

The view of citizenship as loyalty, identity, and territorial authority, which form a tight unit dating from the $19^{\text {th }}$ century, underwent fundamental changes in the twentieth and twenty-first centuries. The international legal development of the past 20 years transformed the relations of the nation-state to its citizens, reducing 
the use of citizenship policy to create a homogeneous mono-cultural society. Thus, the traditional nation-state, united in the trinity of the nation, its territory, and the state, cannot serve as the only basis for analysing citizenships in the $21^{\text {th }}$ century (Csergő 2000, Csergő-Goldgeier 2007).

The principle of territorial sovereignty, which has dominated the international system since the Peace of Westphalia in 1648, has been weakened through the processes of globalization, migration, and regionalization. Alternative forms of organizations emerged, which sought to replace the Westphalian system of sovereign states. New supranational institutions and the institutionalization of human rights increasingly question the sovereignty of the nation-state.

The possibility to travel has become available to an ever-widening range of people as more and more people moved outside their native countries in search of jobs. The freedom of movement, patterns of migration, and the availability of information through the Internet moved the world towards new types of citizenships. These include, among others, supranational, global, transnational, and post-national citizenships. Some scholars advocate citizenship in subnational territorial units as a way of furthering the participation in public life of those who live there regardless of nationality and citizenship. This would involve the de-linking of national and local citizenship (Held 1995, Pogge 1997).

One example of the new type of citizenship is the European Union citizenship, which allows citizens of the EU to vote in their place of residence. A growing number of citizens live and work outside their homeland in the European Union, which has become a supranational institution for EU citizens (Szabó 2013). The EU created a special legal community in which EU citizenship connects the 500 million citizens of the EU member states. Bauböck describes this special status of EU member states as 'denizenship' (Bauböck 2005). Under this form of citizenship, a person who lives in another EU member state has almost the same political and civil rights as the citizens of the host state. Those EU citizens who settle in another EU state can participate in the local and EU elections. Except for the right to participate in national parliamentary elections, they have full rights. Under these arrangements, national citizenship has lost much of its meaning (Szabó 2013: 143 in Papp 2014).

Scholars also identify the category of global citizenship. This encompasses persons who give preference to ties with national organizations such as Amnesty International or Greenpeace over ties to a national community (Bloemraad 2008: 166).

Bauböck introduces the concept of stakeholder citizenship, under which citizens are those who have a stake in the polity's future because of the circumstances of their lives, that is, through their ties to a country where they are deeply involved in political life. This concept is directed toward Western countries which absorb a growing number of immigrants and face difficulties 
in the integration of the newcomers. It supports the granting of citizenship to immigrants to enable them to participate in the collective decision-making process. Under stakeholder citizenship, both immigrants and emigrants who live outside the country should be granted citizenship, and the states should respect the individual's decision to give one affiliation priority (Bauböck 2007: 242).

\section{Dual Citizenship: from Rejection to Acceptance}

Rejected by many countries well into the $20^{\text {th }}$ century, dual and multiple citizenships became accepted throughout the world as a result of global developments (Schöpflin 2003). Dual citizenship came to play a key role in the emergence of transnational and deterritorialized identity structures (Bauböck 2007).

In the nineteenth century, the idea that a person could be a citizen of two or more states was strongly rejected because of the conviction that those living on the territory of a sovereign state can only belong to that state. In 1849, US Ambassador George Bancroft likened dual citizenship to bigamy. In his view, one should 'as soon tolerate a man with two wives as a man with two countries' (qtd in Koslowski 2000: 206). In 1930, a League of Nations convention declared that everyone should have only one nationality (Blatter 2011: 771, Spiro 2010: 111-130). There was a great deal of mistrust toward persons aspiring to be dual citizens, and the taking up of the citizenship of another state resulted in most cases in the loss of the other citizenship. The assumption was that a person could not be loyal to two states and was playing a double game.

This attitude of rejection underwent major changes especially on the European continent. The peace treaties following World War I and World War II changed the borders for millions of people, and many found themselves as minorities on the territories of newly formed states. The incongruence between nation-state and territory has greatly increased. In Western Europe, an increasing number of migrants could obtain double citizenship.

With the disintegration of Yugoslavia and the Soviet Union, borders changed again as new states were created, and millions of people lost their citizenship. Many former Soviet citizens settled, for instance in the Baltic States, were denied citizenship in the newly formed states. Over one million Russians took advantage of Russia's offer of citizenship to them. These developments promoted the dilution of the classical meaning of citizenship consisting of the nation-state with a well-defined territory for its nationals.

The European Convention on Nationality (adopted in 1997) was a major breakthrough for the acceptance of multiple citizenship. The Convention promotes the de-ethnicization of citizenship by forbidding differentiation between citizens on the basis of national or ethnic origin as well as religion, race, 
or skin colour. A country can, however, pass legislation that makes it easier to acquire its citizenship for those who belong to it culturally, linguistically, or on the basis of ethnicity. The Convention stated that '[e]ach state shall determine under its own law who are its nationals' and that 'each state is free to decide which consequences it attaches in its internal law to the fact that a national acquires or possesses another nationality'. ${ }^{1}$

This meant that as long as laws regulating access to citizenship harmonize with international agreements, international common law and recognize principles of law, states have a wide-ranging freedom to decide whom they regard as their nationals. States adopted a great number of different approaches to citizenship policy as they set the criteria for determining whom they regard as their own citizens. They granted citizenship to their non-resident nationals and passed legislation that lays down the rights and obligations (Szabó 2013).

The Bolzano/Bozen Recommendations on National Minorities in Inter-State Relations issued by the High Commissioner on National Minorities of the Organization for Security and Cooperation in Europe in 2008 made clear that ties to a national community were also grounds for granting multiple citizenship. ${ }^{2}$ Under the recommendations, the state could take into account historical, cultural, family ties as well as linguistic affinities when granting citizenship to those who live abroad (Szabó 2013: 134). Patrick Weil argues that as states gave up their mistrust of dual citizens, they turned to 'forging an alliance with those possessing multiple nationalities. Dual citizens are part of the strategy of nation-states in a globalised world.' States increasingly regarded dual or multiple citizens as 'possible transmitters of national values and interests abroad. In a globalised world, they can become agents of state influence overseas, diffusers of the national culture or interest, and part of a global network' (Weil 2011: 631).

\section{Nation and State in Citizenship Conceptions}

Eastern and Western conceptions of national citizenship vary because of the different historical experiences of the two regions, which shaped their definitions of whom they regard as members of the nation. Historically, the state and the nation are interconnected, regardless of whether the nation developed in an already existing state or whether the state was formed around an already existing nation. Czech historian Miroslav Hroch points to the different legacies of Western and Eastern and South-Eastern Europe in nation-building. Western nations were products of a long process of nation-building that reached back to the Middle Ages.

1 http://conventions.coe.int/Treaty/en/Treaties/Html/166.htm.

2 The Bolzano/Bozen Recommendations on National Minorities in Inter-State Relations (OSCE HCNM 2008). 
Here, the national movements of the $19^{\text {th }}$ century took place under constitutional conditions and at a time when capitalism began to take roots. Nationally relevant conflicts could find an expression in political terms. In the West, the nation was usually formed in a state framework, and the concept of citizenship is derived mainly from birth on the territory of the state or naturalization. This conception of citizenship regards citizens as members of civic communities who share common political values, respect the same institutions, and live on the same state territory. In Eastern and South-Eastern Europe, nation-building began around 1800. The elite groups lacked political experience and articulated conflicts in national categories (Hroch 1985). They mobilized the nation around ethnicity before the state was formed, and the ethnic origin (jus sanguinis) principle was given priority. Mobilization around ethnicity was necessary to achieve national independence from the empires in which the nations were incorporated. Membership in the nation was defined in ethno-cultural terms, taking common descent and heritage as its basis. As many nationalities in Eastern Europe became minorities in their historic native land following wars and the disintegration of empires, the ethnocultural recognition came to play a key role in the conceptions of citizenship (Kohn 1944, Meinecke 1962).

National traditions also play a great role in Western Europe in what type of citizenship policy is adopted. France has dealt with migrants according to the republican principle of granting citizenship to those born on its territory, which arguably offered them a greater chance of inclusion but also required them to abandon their culture and refused to recognize them as ethno-cultural groups. Other Western countries, such as the Netherlands, accept cultural pluralism, and small groups of minorities can maintain their unique cultural identities.

Germany's 'policy on aliens' (Ausländerpolitik) was until recently strongly shaped by an ethno-cultural notion of national identity and citizenship. In 2000, Germany gave up its strict commitment to single citizenship to further the process of integration of the Turkish minority. Children born in Germany to immigrant parents can have dual citizenship but must give up foreign citizenship between the ages of 18 and 23 in order to retain their German citizenship. ${ }^{3}$ Migrants arrived in Germany as guest workers in the 1960s and were joined by many others who fled economic deprivation. Similarly to other Western countries, Germany had increasing problems with integrating the migrants, especially the second and third generations (Koslowski 2000). Regardless of the approaches taken toward migrants, Western countries with large Muslim populations had to grapple with problems of integration.

3 http://www.auswaertiges-amt.de/EN/EinreiseUndAufenthalt/Staatsangehoerigkeitsrecht_node. html. 


\section{Nationalism and Revival of the Nation}

In Eastern and South-Eastern Europe, where ethnicity historically played a prominent role, a revival of the nation took place following the collapse of communism as people in a newly democratized Eastern Europe sought to reconstruct their ethnic identity. This inevitably caused tensions especially in the regions where the boundaries of the state and nation were not congruent. Some nations were even prepared to go to war for ideals that claimed to protect their ethnic identity (Harris 2009: 172-175, Linz-Stepan 1996, Kymlicka-Opalski 2001).

I use the concept of nationalism as a framework to explain the revival of the nation and the citizenship policy of Eastern European nations. According to my definition, nationalism is a social process that seeks to organize and institutionalize society along ethnic lines. Nationalism was swept under the rug during communism and erupted with great force with the advent of democracy. In post-communist Europe, nationalism serves as one of the fundamental organizing principles of nation-states that proved to be the most important nation-building force. Political actors engaged in nationalism seek to create and maintain the cultural identity of the nation or the national minority by institutionalizing societies on a national basis. Nations, majority, and minority pursue their own nationalizing projects to preserve their identity and culture. The efforts of the kin-state to support its ethnic kin and to establish a legal or political relationship to them by granting them citizenship is a reflection of nationalism (Kántor 2014).

Most Western scholars had not anticipated a national revival following the collapse of communism and the measures of nation-states to help their conationals retain their identity. They assumed that nationalism died out under communism and predicted a post-national wave following the democratization of the 1990s, which would transform the identities of populations and make the assimilation of ethnic minorities easier. The international community was not prepared for the ethno-national resurgence either. Neither the EU nor international organizations succeeded in formulating clear norms relating to kin-state action and minority rights protection (Schöpflin 2003).

\section{Dual Citizenship: Integration and Nation-Building}

In Western Europe, double citizenship is seen primarily as a measure to help the integration of migrants and to enhance the well-being of citizens by, for example, enabling them to live in different countries and to participate in political life. The political or civic concept of the nation as a group of people living together on a territory regardless of nationality was strengthened as a growing number of nation-states allowed migrants to become naturalized citizens based on extended 
residence and/or birth in the country rather than filiation. Citizenship based on the principles of ethnic origin or on birth on the territory of the state was increasingly merged. Human rights became separated from the formal citizenship status and membership, and the fundamental rights of a person were not tied to the formal citizen status but to his or her person or residence status (Bloemraad 2008: 154).

The issue of migrants' rights to citizenship in the countries where they lived, often over several generations, was presented by most of the scholarly community as their individual human rights. The political concept of the nation was strengthened as an increasing number of nation-states allowed migrants to become naturalized citizens based on extended residence and/or birth in the country rather than filiation. This led to a merging of citizenship based on the principles of ethnic origin and birth on the territory of the state.

The human rights approach represented a challenge for autochthonous minorities because it focused on individual rights instead of the collective rights needed for the reproduction of their communities. The Western approach also generalized the problems of minorities and failed to take into account that there are differences between the status of minorities who came out of their own free will as migrants and those who stayed in their homelands and the borders moved around them. (Thus, the issue of the establishment of a Hungarian-language university in Transylvania was linked to the setting up of a Turkish university in Berlin.)

Rainer Bauböck defined citizenship that reaches across the borders as transnational citizenship (Bauböck 2003). Transnational citizenship is conceived of as deterritorialized citizenship, which transcends territorial boundaries and allows large groups of people to be citizens of several states. In Western literature, migrants and the sending and receiving states are identified as the forces behind transnationalism (Leggewie 2013). According to scholars, transnational citizenship represents a modern meaning of 'belonging' where national, social, and individual forms of identity are combined (Blatter 2010). Voting rights for non-residents serves as an example of how citizens share their identities and allegiances. Iván Halász speaks of the transborderization of elections, which has reached the Central European region and involves not only the migration of electors but also that of elections and election mechanisms. ${ }^{4}$

Transnational citizenship has also spread to Eastern Europe, but here citizenship was used as a tool of nation-building across state borders. Bauböck designated the rights given by the kin-state to the ethnic kin abroad such as quasicitizenship or citizenship as ethnizenship because it is 'generally granted to minorities on the basis of ethnic descent and perceived common ethnicity with an external kin state' (Bauböck 2007: 2396). In contrast to the migrants in Western Europe, ethnic kin or autochthonous minorities outside the borders of the kin-

4 https://www.jus.uio.no/english/research/news-and-events/events/conferences/2014/wcclcmdc/wccl/papers/ws6/w6-halasz.pdf. 
state did not leave their places of birth voluntarily and retained their loyalty to the kin-state. Autochthonous minority communities were able to define their identity ethno-culturally and sought the help of the kin-state in reproducing their identity. A growing number of kin-states crafted legislation that granted financial aid and preferential treatment to their ethnic kin. Many kin-states used double citizenship with non-resident voting rights as a tool for nation-building that strengthens not only the identity of the ethnic kin but also the social cohesion of the kin-state. Numerous scholars welcomed double citizenship for migrants in Western Europe but rejected it for autochthonous minorities in Eastern Europe (Kymlicka-Opalski 2001).

For many Eastern European minorities, gaining the citizenship of the kin-state was a long-awaited recognition of their ethnic identity and a support for their communities. One could define the citizenship policies of post-communist states as attempts at state-building where the nation serves as the constitutive principle, and the great variety of kin-state legislation reflects the differences in how the states relate to their co-nationals abroad. As Irina Culic puts it:

Broadly speaking, citizenship policies in post-communist countries have been the result of individual and competing state-building processes: political elites were constructing both internal and external boundaries for the newly formed or redefined states. As such, constitutional provisions regarding kin living abroad, and citizenship legislation provisions regarding dual citizenship for non-resident co-ethnics were expressive of various visions of the states, and their political, symbolic, and territorial grasp (Culic 2009: 20).

The states used double standards in their approach to dual citizenship by offering it to their ethnic kin but criticizing other states for doing the same if their co-nationals lived on their territory (Culic 2009).

The idea of using citizenship as a tool of nation-building across state borders has precedents in Western Europe. Austria's 1979 law toward German speakers in South Tyrol and Ireland's policies in Northern Ireland are well-known examples. The West German state granted preferential naturalization to ethnic Germans requesting 'repatriation' during the decades of communism. Israel followed a similar policy toward Jews from Ethiopia or from then communist countries. In addition, citizenship to non-residents is a widespread international praxis and has also been adopted by some EU member states such as France, Germany, Spain, and Sweden (Tristan et al. 2013). 


\section{Trans-Sovereign Nationalism}

Zsuzsa Csergő used the concept of 'trans-sovereign nationalism' to describe the policy of the kin-state which reaches across existing borders to its ethnic kin and seeks to help it maintain its ethnic identity (Csergő 2000, Csergő-Goldgeier 2006). Under trans-sovereign nationalism, the kin-state seeks to reconstitute the nation across the borders and achieve 'national reunification' without changing the borders. The Hungarian government adopted a 'trans-sovereign strategy' because the options of building a classical nation-state or the repatriation of ethnic Hungarians were judged as unrealistic. The idea of border revision was not an option in the current international order; the 'velvet divorce' of Czechoslovakia and the Baltic States' regaining independence were the exceptions. Szabolcs Pogonyi summarizes the strategy of the Orbán government toward the ethnic kin as the "national reunification beyond the borders in the rhetoric framework of a borderless Europe, in which individuals may cultivate transnational ties and minority rights (including cultural and territorial autonomy) /and/ are safeguarded by international treaties' (Pogonyi 2015).

However, the home states where ethnic Hungarians live, reject the idea of 'reunification', the 'spiritualization', or 'virtualization' of the borders, qualifying these as interference in their internal affairs. The home states where Hungarian ethnic kin live are, with the exception of Romania, new states, which were established or regained their sovereignty after decades of communism. The home states see in Hungarian trans-sovereign nationalism a challenge to their territorial sovereignty. Irina Culic expresses the fears of the home states:

Dual citizenship for members of the 'people'/ nation abroad is conceived here as the most appropriate way of protecting their cultural identity, way of life, and interests within the home state, and ensuring their thriving outside the borders of the nation-state. In such situations, dual citizenship provides an avenue for direct intervention over non-resident co-ethnics, and formalizes an encroachment of one state over the national policies of another state (Culic 2009).

One of the challenges is to harmonize the principles of state sovereignty with nation-building across state borders. The kin-state, the home state, and the minorities are the major actors in this process. The EU acted as a mediator between the three actors and had the power to influence the policy toward minorities because all post-communist states sought to comply with EU norms in order to gain entrance to the Union. Home states agreed to give up part of their sovereignty to the EU and were prepared to make some concessions on granting minorities more rights in order to join the EU (Kymlicka-Opalski 2001). 


\section{Political Nation versus Ethno-Cultural Nation}

The Hungarian dual citizenship to the ethnic kin abroad sparked debates not only in the home states but also in Hungary. In contrast to other Eastern European countries which implemented similar measures, in Hungary, there is no consensus among the political elite over granting double citizenship to the ethnic kin and the role of the kin state in representing the interests of Hungarian co-nationals. This debate revolves around who belongs to the Hungarian nation and has been going on since the beginning of the twentieth century (Gyurgyák 2007). Under communism, the issue of nation and ethnic Hungarians was hardly discussed in public. After the collapse of communism, the Hungarian government and public was confronted with the fact that the large number of Hungarians who live outside the country's borders claimed their minority rights and turned to the kin state for help in maintaining their ethnic identity (Bárdi 2004).

The current debate over granting double citizenship illustrates the clash in Hungary over the political and the ethno-cultural views of the nation. The issue of who belongs to the nation was swept under the carpet under communism and re-emerged under democratic conditions. Bárdi divides the conflicting discourses surrounding membership in the nation into 'anti-national' and 'national' attitudes and identifies their roots in the conflicts between Hungarian political camps that emerged following the democratization. Bárdi sees no prospect for a consensus between the two sides in the foreseeable future because in his view the discourses run parallel and create cohesion in the respective political camps (Bárdi 2004, Bárdi 2013).

The left liberal political elite objects to granting the ethnic kin double citizenship on the ground that they do not live in the country and should not be involved in taking decisions that affect the population in Hungary. They regard the ethnic minorities as citizens of the country where they live and hold their home state responsible for improving their lot (Pogonyi 2011, Egry 2010).

Under this view, good neighbourly relations have priority in bilateral relations, and the Hungarian state must negotiate with the home states before taking measures affecting the status of the ethnic minorities who live on their territory. The conservative political camp views the ethnic kin as integral part of the Hungarian nation, whose rights should have priority in bilateral relations to the home states. On the issue of double citizenship, conservatives opine that it is likely that even home states which have similar legislation toward their ethnic kin would have rejected it for ethnic Hungarians because of deep-seated suspicions over Hungarian intentions.

In the debate over double citizenship, many Hungarian scholars expressed approval for the double citizenship for migrants but not for their ethnic kin abroad (Búr-Baky 2005, Pogonyi 2011, Blokker-Kovács 2015). They regarded 
double citizenship to migrants as a positive step toward the de-ethnicization of citizenship. Blokker and Kovács expressed the hope that double citizenship to migrants would decrease 'nationalistically informed, closed attachments to majority groups and their culture' and reflect 'a more cosmopolitan, open understanding of citizenship'. They warned that in the case of ethnic minorities 'dual citizenship can equally be related to forms of re-emphasising national, state sovereignty of the closed, modern, and Westphalian kind and legal pluralism can relate to attempts to extend a sovereigntist logic beyond state borders in an attempt to deterritorialise but also increase nationalistic forms of sovereignty' (Blokker-Kovács 2015: 2).

Hungarian ethnic kin in neighbouring countries adopt as a rule the ethnocultural view of the nation and stress that while they are citizens of the home state they belong to another nation culturally. In their view, under the political concept of the nation, they are not allowed to decide which nation they belong to based on their cultural heritage, and, instead of that, others decide for them what their citizenship is based on. If this is correct, Swedes in Finland, Catalans, and many other nationalities exist only as part of the political nations where they live, and their minority rights have no foundation. Yet, nationalities are recognized and have rights in most countries of the European Union (Öllös 2006).

For ethnic Hungarians in neighbouring countries and for ethnic minorities in general, the key issue is that they do not have equal chances with the majority to succeed in their home state and cannot reproduce themselves as a community. Ethnic minorities point out that home state legislation favours the majority, and the minority does not have group or collective rights that would allow them to have a say in legislation concerning their cultural and educational life (Öllös 2006).

Many ethnic Hungarians in neighbouring countries regard Hungarian citizenship and voting rights as a historical compensation for the injustice they suffered at the hands of the majority of the state where they found themselves. Surveys and statistics indicate that the majority of ethnic Hungarians welcomed double citizenship. Close to 800,000 ethnic Hungarians applied for Hungarian citizenship by the end of 2015, mostly from Transylvania. By August 2015, over 700,000 took the oath of citizenship. ${ }^{5}$ The reasons for taking up Hungarian citizenship varied from possibilities to travel and work abroad for those whose home states are not members of the EU to a sense of belonging to the kin state. For many, Hungarian citizenship gave recognition to their ethnic identity and a sense of security towards the home state (Pap 2014).

5 Deputy PM: the number of applications for Hungarian citizenship expected to reach 800,000 by the end of the year. 15 August 2015, Hungary Today: http://hungarytoday.hu/news/deputy-pmnumber-applications-hungarian-citizenship-expected-reach-800-000-end-year-25751. 5 August 2015, MTI: http://dailynewshungary.com/semjen-encourages-ethnic-hungarians-in-westukraine-to-take-citizenship/. 31 December 2015, Interview with Zsolt Semjén, Radio Kossuth. 


\section{Majority and Minority}

The key question of citizenship policy in both Western and Eastern Europe is to find ways how majority and minority can live together in a way that the rights of both sides are respected. Scholars identified two key approaches that can facilitate the peaceful co-existence of majority and minority. One arrangement can be defined as integrative and the other as consociational. The integrative approach aims to reduce ethnic cleavages and increase interaction between majority and minority. Here competition takes place along non-ethnic lines. The consociational approach, on the other hand, seeks to institutionalize ethnic cleavages and limit the interactions to the political elite. In this way, majority and minority can have their parallel societies, which can serve as the pillars of society. It was Arend Lijphart who set up the theory that forms the basis of these studies, who envisioned a consociational or power-sharing model of democracy for societies where deep divisions were present. Such a power-sharing model could be successful if 1.) the elite is willing to put its difference aside and enter a grand coalition; 2.) the right of mutual veto is accepted; 3.) if society is willing to accept the depoliticization of various segments and institutions; 4) the acceptance of proportionality; 5) granting autonomy to different groups (Daalder 1974, Lijphart 1996).

Hungarian ethnic parties opted for consociational power-sharing by participating in the majority government. The problem is that the structural and institutional guarantees needed for consociationalism are missing, and thus only the first requirement listed by Lijphart is fulfilled. In the absence of such guarantees, minority rights are subject of political deals between minority and majority and can easily be taken away. For this reason, one can describe the motto of the arrangement between minority and majority in this case as 'moderation through inclusion' because ethnic Hungarian parties tended to moderate their demands for more minority rights when they participated in the majority governments (Székely 2014).

In Western Europe, governments tend to opt for the integrative approach, which aims to reduce ethnic cleavages and increase interaction between majority and minority. Here competition should take place along non-ethnic lines. This is, however, very difficult to implement. It depends on the willingness of the minority to give up its ethnic characteristics. In most Western countries, migrants created their own parallel societies and had no wish to fully integrate into the majority society. This was even promoted by scholars, who interpreted this as multiculturalism and welcomed it as a way of life where each nationality can hold on to its separate traditions. Questions about the success of this approach were raised in the early 2000s, when studies showed that the second and third generations born in Western Europe were less integrated than their parents and could hardly speak the language 
of their host country (Egedy 2016). The lack of language skills and education placed many of these migrants in a socially disadvantaged position that left them perceptible to extremism (Bodemann-Yurdakul 2006).

\section{Whither Nation-State?}

Many Western scholars opine that the nation-state is on the decline and will disappear in time (Joppke 2006, Leggewie 2013). The role of the nation-state and national citizenship are hardly taken into account in studies of globalization and transnational migration. Voices that express doubts about the imminent death of the nation-state are ignored as a rule by the dominant narrative, which considers these voices unscientific. The nation-state is deemed as something antiquated and is mentioned with the prefixes like 'post-', 'trans-', and 'supra-' to indicate its decline. Predictions about the demise of the nation-state go hand in hand with the legitimacy crisis of 'nationality' and of national state citizenship (Pogonyi 2011). As Patrick Weil formulates it: 'Nationality is said to have been undermined both by external competition from other affiliations (sub-, trans-, or supranational, ethnic, religious, gender-related, etc.) and by its own inegalitarian qualities' (Weil 2011: 615).

Studies about the demise of the nation-state are closely linked to issues relating to the rights of migrants. Scholars focus on the rights of migrants to political participation and citizenship and put pressure on nation-states to implement changes in the criteria of granting citizenship and voting rights. They used the international human rights regime to argue against the claims of nation-states to control access to their territory (Joppke 2005).

A favourite topic of post-national projects is the 'liberation' of citizenship from nationality. Scholars suggested that the nation-state should give up its ethnic character and act as a neutral mediator between majority and minority (Joppke 2006). Joppke defines 'de-ethnicization' 'as the process of facilitating the access to citizenship, either through opening it at the margins in terms of liberalised naturalisation procedures or through adding jus soli elements to the modern main road of birth-attributed citizenship jure sanguinis' (Joppke 2006: 69). Joppke names two basic conditions that have to be met for the 'de-ethnicization' of the state to take place: 'first the decoupling of the state from nation-building; second, the existence of a political force, usually on the left, to wage a reform that promises few if any votes'. He recalls the importance of a 'self-limiting' understanding of nation-building in a liberal state', under which 'liberal norms constrained what states could do in the domain of immigration and citizenship policy' (Joppke 2006: 70, Kymlicka 2002).

In contrast to the efforts by liberal scholars to de-ethnicize citizenship, the kinstates where migrants come from are more interested in re-ethnicizing citizenship. 
They tend to allow their emigrants to keep their citizenship when they naturalize elsewhere because this allows them to retain ties with their ethnic kin and reap the material and political benefits from it. While the de-ethnicization trend concentrates on the territorial nature of the state, 're-ethnicization cuts across the "ethnic versus civic" distinction known from the nations and nationalism literature, as it is grounded in the ascriptive membership component of the state' (Joppke 2006).

The idea that citizenship should be liberated from nationality and a new form of citizenship based on human rights should be introduced is very controversial among the public in both Western and Eastern Europe and reflects the politicization of the topic of citizenship policy. The approach to citizenship as a human right would have wide-reaching implications for citizenship policy toward the ever-growing migrant population. There is also a debate in Western Europe about who should be regarded as a member of the national community and be granted citizenship (Greenfeld 1992, Hobsbawm 1992, Hroch 1985).

There is a cleavage between the views of the scholarly community and popular opinion in many Western countries faced with massive migration. Scholars tend to adopt the civic-territorial or political view of the nation, while citizens concerned about a weakening of national traditions stress the ethnic-cultural. Joppke represents the views of many scholars as he declares that 'the political process in electoral democracies is endemically vulnerable to the populist pressure of majority opinion' (Joppke 1999: 18 qtd in Culic 2009).

Other scholars, such as Weil, argue that the crisis of the nation-state and citizenship is exaggerated. Weil even detects 'a new vitality' of national state citizenship in the face of globalization and technological development and asserts that 'a new strategic collaboration between the individual and the state has emerged as their interests have converged' (Weil 2011: 615, Hansen 2008). He comes to the conclusion that 'for the time being, national citizenship remains strong, and not only in the European Union. Indeed, citizenship remains the sole basis of certain rights - international protection, right of repatriation, political participation, and protection against expulsion - without which the individual would be denied fundamental entitlements' (Weil 2011: 617).

\section{Conclusions}

An analysis of the citizenship policies in Eastern and Western Europe showed that the two regions differ in how they define membership in the community. The role of the state and the nation in establishing social cohesiveness is a major difference that has historical roots. In Eastern Europe, the nation was formed first and the state was built around it, which gives the nation a prominent role. 
In Western Europe, the state plays a greater role than the nation because statebuilding took place mostly before or concomitantly to nation-building. Following wars in the twentieth century, many nations in Eastern Europe found themselves as minorities in neighbouring countries. After decades of communist rule, the nation had to be reconstructed in Eastern Europe, and many countries are still engaged in simultaneous nation- and state-building. Western Europe did not experience communism and came to great economic prosperity. In the 1990s, at the beginning of the democratic transformation in Eastern Europe, well-functioning democracies were already in place in the West. Western Europe grappled with the integration of millions of migrants who settled there and sought to promote their integration by granting them citizenship. In Eastern Europe, most countries offered citizenship to their ethnic kin in neighbouring countries in order to help them protect their ethnic identity. Thus, while the West moved towards the direction of de-ethnicizing citizenship in order to integrate migrants, in Eastern Europe, citizenship was used to strengthen the identity of the nation by granting citizenship to ethnic kin across the borders. In the West, a major group of scholars designated the nation-state as outdated and promoted citizenships that transcended it. According to this view, the state had to give up its ethnic character and act as a neutral mediator between majority and minority. Thus far, however, no state in Western or Eastern Europe shed its ethnic character, and many European countries seek to retain their national heritage. The experiences of autochthonous minorities confirm that the nation-state has not given up its ethnic character and does not function as a neutral mediator between minority and majority. The nation-state promotes the history and culture of the majority in education and language policy. The debates on collective rights, autonomy, and language use make it clear that the nation-state represents the interests of the majority and builds the majority nation-state at the expense of the minority. Thus, one can conclude that while the autonomy of the nation-state has been curbed as a result of recent global developments, nation-states have an important role to play in representing the interests of their citizens and ethnic kin as well as in shaping the process of globalization.

\section{References}

ALBERT, Mathias-JACOBSON, David-LAPID, Yosef (eds). 2001. Identities, Borders, Orders. University of Minnesota Press, Minneapolis.

ANDERSON, Benedict. 1983. Imagined Communities: Reflections on the Origin and Spread of Nationalism. Verso, London.

ARENDT, Hannah. 1973. The Origins of Totalitarianism. Harvest/HBJ Book, San Diego-New York-London. 
BAUBÖCK, Rainer. 2003. Towards a Political Theory of Migrant Transnationalism. International Migration Review 37: 700-723.

2005. Expansive Citizenship: Voting beyond Territory and Membership. Political Science and Politics 38(4): 683-687.

2007. Stakeholder Citizenship and Transnational Political Participation: a Normative Evaluation of External Voting. 75 Fordham L. Rev. 2393. Available at: http://ir.lawnet.fordham.edu/flr/vol75/iss5/4.

BÁRDI, Nándor. 2004. Tény és való [Fact and Reality]. Kalligram, Pozsony [Bratislava].

2013. Nemzetstratégiáról, külhoni magyarságról, „táposokról” [About National Strategy, Hungarians Abroad, 'Feeders']. Source: http://www.maszol. ro/index.php/tarsadalom/17025-bardi-nandor-nemzetstrategiarol-kulhonimagyarsagrol-taposokrol September 1 2013. Accessed on: 13 January 2015.

BENHABIB, Seyla. 2004. The Rights of Others: Aliens, Residents and Citizens. Cambridge University Press, Cambridge.

BLATTER, Joachim. 2010. Dual Citizenship for Ethnic Minorities with Neighbouring Kin States. In: BAUBÖCK, Rainer (ed.), Dual Citizenship for Transborder Minorities? How to Respond to the Hungarian-Slovak Tit-ForTat. European University Institute Working Paper, Robert Schuman Centre for Advanced Studies, RSCAS 2010/75.

BLOKKER, Paul-KOVÁCS, Krisztina. 2015. Hungarian Citizenship and Franchise Politics and Their Effects on the Hungarian-Romanian Relations. In: BASHESKA, Elena-KOCHENOV, Dimitry (eds), The Principle of Good Neighbourly Relations in Europe: Theory and Practice. Brill/Nijhoff, Leiden. BODEMANN, Y. Michal-YURDAKUL, Gökçe (eds). 2006. Migration, Citizenship, Ethnos. Palgrave Macmillan, New York.

BLOEMRAAD, Irene-KORTEWEG, Anna-YURDAKUL, Gökçe. 2008. Citizenship and Immigration: Multiculturalism, Assimilation, and Challenges to the Nation-State. The Annual Review of Sociology 34: 153-179.

BOSNIAK, Linda. 2003. Multiple Nationality and the Postnational Transformation of Citizenship. In: MARTIN, David-HAILBRONNER, Kay (eds), Rights and Duties of Dual Nationals. Evolution and Prospects. Kluwer Law International, The Hague-London-New York, 27-48.

BRUBAKER, Rogers. 1992a. Citizenship and Nationhood in France and Germany. Harvard University Press, Cambridge.

1992b. Citizenship Struggles in Soviet Successor States. International Migration Review 26(2): 269-291.

1996. Nationalism Reframed. Nationhood and the National Question in the New Europe. Cambridge University Press, Cambridge.

BƯR-BAKY, Miklós. 2005. Az alkotmány őre [The Guard of the Constitution]. Magyar Narancs 35: 172-173. 
CULIC, Irina. 2003. State Building and Constitution Writing in Central and Eastern Europe after 1989. Regio 1(3): 38-58.

2006. Dilemmas of Belonging: Hungarians from Romania. Nationalities Papers 2(34): 175-200.

2009. Dual Citizenship Policies in Central and Eastern Europe. Working Papers in Romanian Minority Studies 15: 5-32.

CSERGŐ, Zsuzsa. Hungary's Trans-Sovereign Project (Ten Years After). https:// www.wilsoncenter.org/publication/201-hungarys-trans-sovereign-project-tenyears-after 7 July 2011. Accessed on: 14 January 2016.

CSERGŐ, Zsuzsa-GOLDGEIER, James M. 2006. Virtual Nationalism in Comparative Context: How Unique Is the Hungarian Approach? 21 ${ }^{\text {st }}$ Century COE Program Slavic Eurasian Studies 9.

2006. Beyond Sovereignty: from Status Law to Transnational Citizenship? Osamu Ieda Slavic Research Center. https://src-h.slav.hokudai.ac.jp/coe21/ publish/no9_ses/16_csergo.pdf. Accessed on: 14 January 2016.

DAALDER, Hans. 1974. Review: The Consociational Democracy Theme. World Politics 26(4): 604-621.

EGEDY, Gergely. 2001. Konzervativizmus az ezredfordulón [Conservatism at the Turn of the Millennium]. Magyar Szemle Könyvek, Budapest, 174-181.

2013. Conservatism and Nation Models in Hungary. Hungarian Review 3. www.ceeol.com.

2016. A multikulturalizmus vége? [The End of Multiculturalism?]. Kommentár 2: 73-86.

EGRY, Gábor. 2010. Otthonosság és idegenség [Feelings of Homeliness and Strangeness]. Napvilág Kiadó, Budapest.

FAIST, Thomas. 2009. The Transnational Social Question - Social Rights and Citizenship in a Global Context. International Sociology 24(1): 7-35.

FAIST, Thomas-KIVISTO, Peter (eds). 2008. Dual Citizenship in Global Perspective. From Unitary to Multiple Citizenship. Palgrave Macmillan, London.

FREY, Bruno S. 2003. Flexible Citizenship for a Global Society. Politics, Philosophy \& Economics 2(1): 93-114.

FURIA, Peter A. 2005. Global Citizenship, Anyone? Cosmopolitanism, Privilege and Public Opinion. Global Society 19(4): 331-359.

GELLNER, Ernest. 1983. Nations and Nationalism. Cornell University Press, Ithaca-London.

GREENFELD, Liah. 1992. Nationalism: Five Roads to Modernity. Harvard University Press, Cambridge-London.

GYURGYÁK, János. 2007. Ezzé lett magyar hazátok. A magyar nemzeteszme és nacionalizmus története [This Happened to Your Homeland. The History of the Concept of the Hungarian Nation and Nationalism]. Osiris, Budapest. 
HABERMAS, Jürgen. 1995. Citizenship and National Identity: Some Reflections on the Future of Europe. In: BEINER, Ronald (ed.), Theorizing Citizenship. State University of New York Press, Albany, NY, 155-282.

HANSEN, Randall. 2009. The Poverty of Postnationalism: Citizenship, Immigration, and the New Europe. Theory \& Society 1(38): 1-24.

HARRIS, Erika. 2009. Nationalism Theories and Cases. Edinburgh University Press. HELD, David. 1995. Democracy and the Global Order. From the Modern State to Cosmopolitan Governance. Stanford University Press, Stanford

HOBSBAWM, Eric. 1992. Nations and Nationalism since 1780: Programme, Myth, Reality. Cambridge University Press, Cambridge.

HROCH, Miroslav. 1985. Social Preconditions of National Revival in Europe: a Comparative Analysis of the Social Composition of Patriotic Groups among the Smaller European Nations. Cambridge University Press, Cambridge.

JOPPKE, Christian. 1999. Immigration and the Nation State. The United States, Germany, and Great Britain. Oxford University Press, Oxford.

2005. Selecting by Origin. Ethnic Migration in the Liberal State. Harvard University Press, Cambridge.

2006. Citizenship between Re- and De-ethnicization. In: BODEMANN, Y. Michal-YURDAKUL, Gökçe (eds), Migration, Citizenship, Ethnos. Palgrave Macmillan, New York, 63-94.

KÁNTOR, Zoltán. 2014. A nemzet intézményesülése a rendszerváltás utáni Magyarországon [The Institutionalization of the Nation in Hungary after the change of Regime]. Osiris, Budapest.

KISS, Tamás. 2015. Defining the Nation. Citizenship Policies, Classificatory Struggles and Discourses Crosscutting the Idea of National Reunification in Hungary and Romania. Manuscript.

KOHN, Hans. 1944. The Idea of Nationalism. A Study in Its Origin and Background. Macmillan, London.

KOSLOWSKI, Rey. 2000. Demographic Boundary Maintenance in World Politics.

In: ALBERT, Mathias-JACOBSON, David-LAPID, Yosef (eds), Identities, Borders, Orders. University of Minnesota Press, Minneapolis.

KYMLICKA, Will-OPALSKI, Magda (eds). 2001. Can Liberal Pluralism Be Exported? Western Political Theory and Ethnic Relations in Eastern Europe. Oxford University Press, Oxford.

LEGGEWIE, Claus. 2013. Transnational Citizenship Ideals and European Realities. http://www.eurozine.com/articles/2013-02-19-leggewie-en.html.

LIJPHART, Arend. 2004. Constitutional Design for Divided Societies. Journal of Democracy 15(2): 96-109.

LINZ, Juan-STEPAN, Alfred. 1996. Problems of Democratic Transition and Consolidation: Southern Europe, South America, and Post-Communist Europe. Johns Hopkins University Press, Baltimore, MD. 
MEINECKE, Friedrich. 1962. Weltbürgertum und Nationalstaat: Studien zur Genesis des deutschen Nationalstaates. Oldenburg, Munich.

NELL, Liza M. 2004. Conceptualising the emergence of immigrants' transnational communities. Migration Letters 1: 50-56.

ÖLLÖS, László. 2006. Nemzet és külpolitika. Magyar Kisebbség 10(41-42): 165185.

ØSTERGAARD-NIELSEN, Eva K. 2003. The politics of migrants' transnational political practices. International Migration Review 37(3): 760-786.

PAPP Z., Attila. 2014. Kisebbségi identitáskonstrukciók [Minority Identity Constructions]. REGIO 22(1): 118-155.

POGGE, T. W. 1997. Migration and Poverty. In: V. Bader (ed.), Citizenship and Exclusion. St. Martin's Press, New York, 12-27.

POGONYI, Szabolcs. 2011. Multiple Citizenship, Multiple Dilemmas. In: Revue Regard sur l'Est. Dossier \#59 "Citoyenneté et Nationalité à l'Est». Source: http://www.regard-est.com/home/breve_contenu.php?id=1275\&PHPSESSID= 08364a58a0236073b8153752c7c36f04. Accessed on: 14 January 2016.

2015. Transborder Kin-Minority as Symbolic Resource in Hungary. Journal on Ethnopolitics and Minority Issues in Europe 14(3): 73-98.

SCHÖPFLIN, György. 2003. A modern nemzet [The Modern Nation]. Attraktor, Gödöllő-Máriabesnyő.

SHORE, Cris. 2004. Whither European Citizenship? Eros and Civilization Revisited. European Journal of Social Theory 7(1): 27-44.

SPIRO, Peter J. 2010 Dual Citizenship as Human Right. International Journal of Constitutional Law 8(1): 111-130.

SZABÓ, Marcel. 2013. A többes állampolgárság - új nemzetközi és uniós perspektívák felé? [The Multicitizenship - Towards New International and Union Perspective]. Állam- és Jogtudomány LIV(1-2): 125-145. Source: http:// jog.tk.mta.hu/uploads/files/Allam-\%20es\%20Jogtudomany/2013_1_2/2013-12-szabo.pdf.

SZÉKELY, István. 2014. Dynamics of Party Politics, Electoral Competition and Cooperation within the Hungarian Minorities of Romania, Serbia and Slovakia (PhD thesis).

MABRY, Tristan James-MCGARRY, John-MOORE, Margaret-O'LEARY, Brendan (eds). 2013. Divided Nations and European Integration. University of Pennsylvania Press, Philadelphia.

WEIL, Patrick. 2011. From Conditional to Secured and Sovereign: the New Strategic Link between the Citizen and the Nation-State in a Globalized World. International Journal of Constitutional Law 9(3-4): 615-635. 